\title{
molecules
}

ISSN 1420-3049

www.mdpi.com/journal/molecules

Article

\section{An Unusual 2,3-Secotaraxerene and Other Cytotoxic Triterpenoids from Pleiocarpa pycnantha (Apocynaceae) Leaves Collected from Nigeria}

Olubunmi A. Omoyeni ${ }^{1}$, Mervin Meyer ${ }^{2}$, Emmanuel Iwuoha ${ }^{1}$, Ivan Green ${ }^{1}$ and Ahmed A. Hussein ${ }^{1, *}$

1 Department of Chemistry, University of the Western Cape, Private Bag X17, Bellville 7535, South Africa

2 Department of Biotechnology, Apoptosis Research Unit, University of the Western Cape, Private Bag X17, Bellville 7535, South Africa

* Author to whom correspondence should be addressed; E-Mail: ahmohammed@uwc.ac.za; Tel.: +272-195-922-62.

Received: 18 January 2014; in revised form: 26 February 2014 / Accepted: 11 March 2014 / Published: 20 March 2014

\begin{abstract}
Three known triterpenoids, namely ursolic acid (1), and the 27-E- and 27-Z-pcoumaric esters of ursolic acid (compounds 2, 3), were isolated together with a new triterpene 2,3-seco-taraxer-14-en-2,3-lactone [pycanocarpine (4)] from an ethanolic extract of Pleiocarpa pycnantha leaves. The structure of $\mathbf{4}$ was unambiguously assigned using NMR, HREIMS and X-ray crystallography. The cytotoxic activities of the compounds were evaluated against HeLa, MCF-7, KMST-6 and HT-29 cells using the WST-1 assay. Ursolic acid (1) displayed potent cytotoxic activity against HeLa, HT-29 and MCF-7 cells with $\mathrm{IC}_{50}$ values of 10,10 and $20 \mu \mathrm{M}$ respectively. The new compound 4 and its hydrolysed derivative $\mathbf{5}$ were selectively cytotoxic to the breast cancer cell line, MCF-7 with $\mathrm{IC}_{50}$ values 20 and $10 \mu \mathrm{M}$ respectively. This is the first report on isolation of a 2,3-seco-taraxerene derivative from the Apocynaceae family and cytotoxic activityof P. pycnantha constituents.
\end{abstract}

Keywords: Pleiocarpa pycnantha; Apocynaceae; triterpenoids; cytotoxicity; 2,3-seco-taraxerene; ursolic acid; WST-1 


\section{Introduction}

Man has used plants for food and medicinal purposes for thousands of years and thereby has acquired detailed knowledge of their properties [1-3]. Medicinal plants have been in use to treat various diseases for many years in different parts of the world [4]. The use of natural products is also on the increase in the Western world [5]. These natural products are used either as standardized plant extract, semi purified or purified forms [6]. According to the World Health Organization [7], about $70 \%-95 \%$ of the world's population in developing countries relies mainly on plants for their primary health care. Traditional medicine remains the only health resource available to about $60 \%$ of the world's population, especially those in the vast rural areas of developing countries [8,9].

Cancer is a major public health burden in both developed and developing countries. According to the global cancer statistics made public by the American Cancer Society in 2007, the total number of cancer deaths per day was 20,000 with $38 \%$ in developed countries and $62 \%$ in developing countries. It was also projected that 27 million new cancer cases and 17.5 million cancer deaths would occur by 2050. Siegel et al. [10] performed one of the most recent studies on cancer incidence, mortality, and survival based on incidence from the National Cancer Institute, the Centers for Disease Control and Prevention, and the North American Association of Central Cancer Registries and mortality data from the National Center for Health Statistics. A total of 1,638,910 new cancer cases and 577,190 deaths from cancer were projected to occur in the United States in 2012. Plants have a long history of use in in cancer treatment [11]. Over $60 \%$ of currently used anticancer agents are derived from natural sources [12,13]. Traditionally, Apocynaceae plants were used to treat gastrointestinal ailments, fevers, malaria, pain, diabetes, ulcers, tuberculosis, helminthosis and cancer [14-19]. Pleiocarpa pycnantha is a shrub or small to large tree attaining of highest up to $30 \mathrm{~m}$ in secondary jungle or in the lower level of the high-forest from Mali to South Nigeria and across Africa to Zaire, Angola, Uganda and Zanzibar. The wood is hard and yellow, and it's used to make combs, plane-blocks and sundry small objects. In Ghana, the roots are added to palm-wine to give it potency. Ground roots mixed with seeds of Aframomum melegueta K. Schum. and palm wine is taken as a laxative. In Benin, leaf maceration with lemon juice is given to patients suffering from jaundice, oedema, reduced urine excretion and infection by roundworms [20]. In the Yoruba speaking part of West Africa a blend of the leaves of P. pycnantha, Spondias mombin (Anacardiaceae) and a fruit of Aframomum melegueta (Zingiberaceae), are combined and administered to gain and retain good memory [21]. Some indole alkaloids e.g., pycnanthine, pleiocarpamine, quebrachamine macusine and (-)-ebunarmine have been isolated from $P$. pycnantha roots and bark [22,23]. Pleiocarpamine has demonstrated anticancer potential [24]. In this work, we explored the anticancer potential of $P$. pycnantha, its extracts and isolated compounds. To the best of our knowledge, this is the first substantial biological activity reported for $P$. pycnantha leaves and the first on isolation of triterpenes for the specie, and the second for the genus.

\section{Results and Discussion}

An ethanol extract of $P$. pycnantha leaves was evaluated for cytotoxicity on cervical carcinoma (HeLa), breast adenocarcinoma (MCF-7), colorectal adenocarcinoma (HT-29) and non-cancerous fibroblast (KMST-6) human cell lines, the extract treatment induced loss of cell viability in a 
dose-dependent manner. However the activity was low with $\mathrm{IC}_{50}>100 \mu \mathrm{g} / \mathrm{mL}$ on all the cell lines, some of the fractions demonstrated potent activity at $<100 \mu \mathrm{g} / \mathrm{mL}$, which gave some justification to carry out further chemical investigations of such fractions. The active fractions were further purified which led to the isolation of the active constituents 1-4 (Figure 1). Repeated chromatography of the fractions P4, P9 and P12 led to the isolation of three known triterpenoids; ursolic acid (1) $[25,26]$, 27-p-E-coumaroloxyursolic acid (2) [27], 27-p-Z-coumaroyloxyursolic acid (3) [28], and a new triterpene, which we have named pycanocarpine (4), which was further hydrolyzed to give the corresponding 2-carboxy-3-hydroxy derivative 5. The known compounds were identified by comparison of their NMR data with published values [25-28].

Figure 1. Chemical structures of isolated compounds from P. pycnantha.
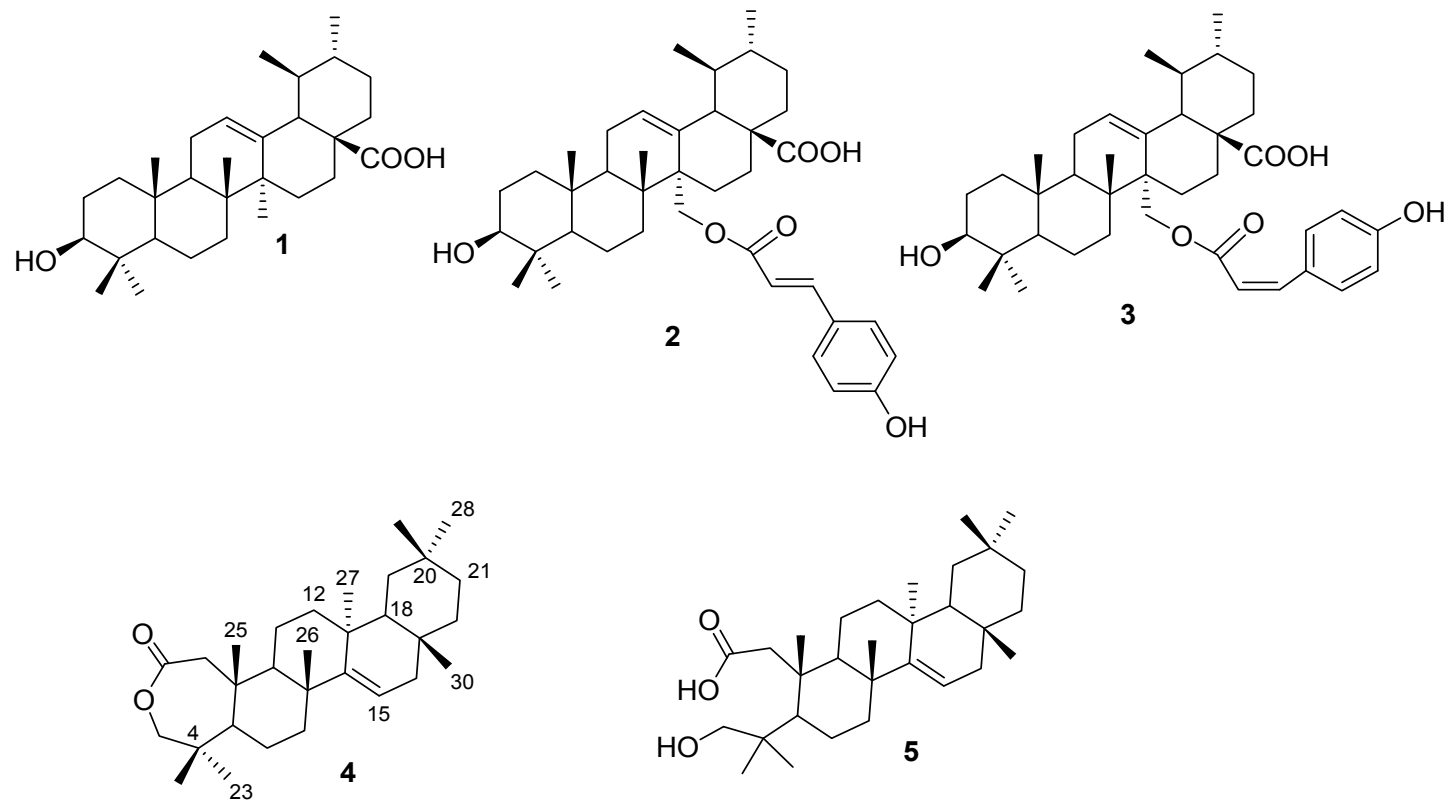

Triterpene esters containing the $E$-coumaric acid isomer have been reported from natural sources, while, the co-existence of $E$ - and $Z$-coumaric acid esters of ursolic acid (compounds 2 and 3 ) in Plumeria obtusa of the same family has been reported once [27,28]. However, although some reports have indicated the photo isomerization of the $E$ isomers to the $Z$ form using UV light [29], we did not observe any such change (as indicated by ${ }^{1} \mathrm{H}-\mathrm{NMR}$ measurements) in any of the isomers during 2-3 months under normal working conditions.

Compound 4 was isolated as colourless needle-like crystals with molecular formula of $\mathrm{C}_{30} \mathrm{H}_{48} \mathrm{O}_{2}$ on the basis of TOF-ESI-MS $m / z 441.3735[\mathrm{M}+\mathrm{H}]^{+}$. The IR spectra showed peaks at $1,738 \mathrm{~cm}^{-1}(\mathrm{C}=\mathrm{O}$ stretching) and $1,474 \mathrm{~cm}^{-1}$ (C-O). The NMR spectroscopic data of 4 are similar to those of $3 \beta$-taraxerol, with differences limited to ring A. The signal due to the olefinic proton at $\delta 5.54(\mathrm{~m})$ together with ${ }^{13} \mathrm{C}-\mathrm{NMR}$ signals of C-14 $(\delta 157.7)$ and C-15 ( $\delta$ 117.1) suggested a taraxerane moiety [30]. The signal at $\delta 174.8(\mathrm{C}-2), 77.9(\mathrm{C}-3)$ in addition to oxygenated methylene protons at $\delta 3.79$ and $4.08\left(\mathrm{CH}_{2}-3\right)$ indicated the presence of a lactone group. The ring $\mathrm{A}$ of compound 4 showed some similarity when it was compared to 4-hydroxy-3,4-seco-ursan-12-en-28-oic acid 3,4 lactone derived from ursolic acid [31] and compared very favourably. The NMR data were assigned unambiguously from 2D NMR spectral analysis of compound $\mathbf{4}$ and its hydrolyzed product $\mathbf{5}$. The structure was finally established from X-ray 
diffraction studies. Figure 2 illustrates the perspective view of the molecule with its relative configuration. The compound was thus assigned as 2,3-seco-taraxer-14-en-2,3-lactone and given the name pycanocarpine. After alkaline hydrolysis, compound $\mathbf{4}$ produced the unstable derivative viz 2,3-seco-3-hydroxy-taraxer-14-en-3-oic acid (5) as an off-white amorphous powder. The TOF-ESI-MS indicated an $\mathrm{m} / \mathrm{z} 459.3889[\mathrm{M}+\mathrm{H}]^{+}$. It was noticeable that the free carboxylic and hydroxyl groups would easily reform the lactone ring after a short time in organic solvents such as methanol and chloroform. The NMR data of $\mathbf{5}$ is similar to the parent compound $\mathbf{4}$ and is illustrated in Table 1. Minor changes were observed between 4 and 5 for carbons C-11, -23, -24, and -26. The stereochemistry of both compounds, especially ring A, may partially explain this. In 4 the carbonyl group is directed into the same plan similar to C-24, -26 and -11 . On the other hand, in derivative 5, the minimized energy conformation (Figure 3) showed different orientations and distances for the $\mathrm{C}_{3}-\mathrm{OH}$ and $\mathrm{C}_{2} \mathrm{OOH}$ groups.

Figure 2. ORTEP diagram for 4.

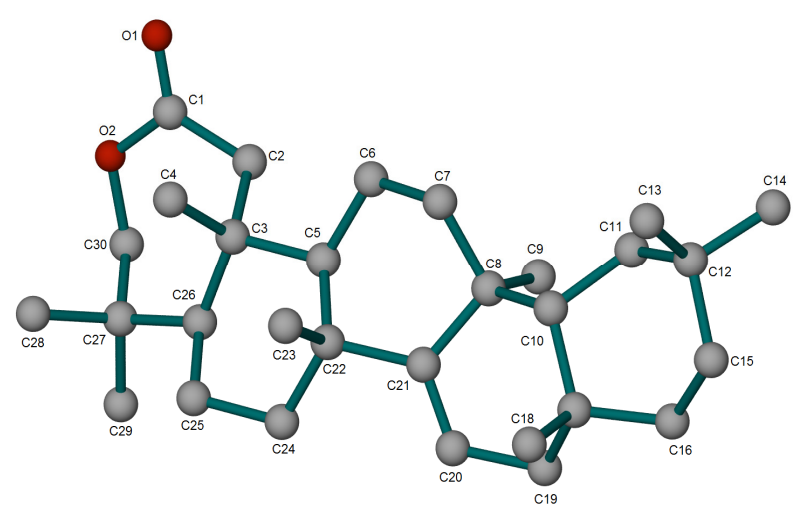

Table 1. ${ }^{1} \mathrm{H} /{ }^{13} \mathrm{C}-\mathrm{NMR}$ data of $4\left(\mathrm{CDCl}_{3}\right)$ and $5\left(\mathrm{CDCl}_{3}+1\right.$ drop $\left.\mathrm{CD}_{3} \mathrm{OD}\right)(\delta$ values, $J$ in parenthesis in $\mathrm{Hz}$ ).

\begin{tabular}{|c|c|c|c|c|}
\hline \multirow{2}{*}{ Position } & \multicolumn{2}{|r|}{ Compound 4} & \multicolumn{2}{|r|}{ Compound 5} \\
\hline & ${ }^{13} \mathrm{C}$ & ${ }^{1} \mathrm{H}(J \mathrm{~Hz})$ & ${ }^{13} \mathrm{C}$ & ${ }^{1} \mathbf{H}(J \mathbf{H z})$ \\
\hline 1 & $44.9 \mathrm{t}$ & 2.44 br s; 2.78 br s & $43.1 \mathrm{t}$ & $2.36 \mathrm{~d}, 2.35 \mathrm{~d},(12.0)$ \\
\hline 2 & $174.8 \mathrm{~s}$ & ----- & $172.9 \mathrm{~s}$ & ----- \\
\hline 3 & $77.9 \mathrm{t}$ & 3.79 br s; 4.08 br s & $72.1 \mathrm{t}$ & $3.33 \mathrm{~d} ; 3.34 \mathrm{~d},(7.0)$ \\
\hline 4 & $38.4 \mathrm{~s}$ & ----- & $38.6 \mathrm{~s}$ & ----- \\
\hline 5 & $48.7 \mathrm{~d}$ & $0.97 *$ & $44.9 \mathrm{~d}$ & $1.72 *$ \\
\hline 6 & $20.6 \mathrm{t}$ & $1.57 * ; 1.66 *$ & $21.8 \mathrm{t}$ & $1.60 * ; 1.53 *$ \\
\hline 7 & $35.1 \mathrm{t}$ & $1.02 * ; 1.35 *$ & $35.6 \mathrm{t}$ & $0.95 * ; 1.34 *$ \\
\hline 8 & $35.8 \mathrm{~s}$ & ----- & $34.9 \mathrm{~s}$ & ----- \\
\hline 9 & $40.9 \mathrm{~d}$ & $1.64 *$ & $42.8 \mathrm{~d}$ & $1.76 *$ \\
\hline 10 & $46.7 \mathrm{~s}$ & ----- & $43.6 \mathrm{~s}$ & ----- \\
\hline 11 & $18.6 \mathrm{t}$ & $1.57 * ; 1.75$ br s & $29.5 \mathrm{t}$ & $1.18 *(2 \mathrm{H})$ \\
\hline 12 & $36.6 \mathrm{t}$ & $0.98(\mathrm{dd} ; 12.0,4.5) ; 1.34 *$ & $37.5 \mathrm{t}$ & $1.49 * ; 1.83(\mathrm{td} ; 9.0,3.5)$ \\
\hline 13 & $37.4 \mathrm{~s}$ & ----- & $37.0 \mathrm{~s}$ & ----- \\
\hline 14 & $157.5 \mathrm{~s}$ & ---- & $157.3 \mathrm{~s}$ & ---- \\
\hline 15 & $117.1 \mathrm{~d}$ & $5.54(\mathrm{dd} ; 8.0,3.5)$ & $116.8 \mathrm{~d}$ & $5.46 \mathrm{dd},(9.0,4.5)$ \\
\hline 16 & $37.8 \mathrm{t}$ & $1.64 * ; 1.92(\mathrm{dd} ; 9.0,2.0)$ & $36.5 \mathrm{t}$ & $0.90 * ; 1.22 *$ \\
\hline
\end{tabular}


Table 1. Cont.

\begin{tabular}{|c|c|c|c|c|}
\hline \multirow{2}{*}{ Position } & \multicolumn{2}{|r|}{ Compound 4} & \multicolumn{2}{|r|}{ Compound 5} \\
\hline & ${ }^{13} \mathrm{C}$ & ${ }^{1} \mathbf{H}(J \mathbf{H z})$ & ${ }^{13} \mathrm{C}$ & ${ }^{1} \mathbf{H}(J \mathbf{H z})$ \\
\hline 17 & $40.6 \mathrm{~s}$ & ---- & $40.2 \mathrm{~s}$ & ----- \\
\hline 18 & $48.7 \mathrm{~d}$ & $0.97 *$ & $48.5 \mathrm{~d}$ & $0.92 *(2 \mathrm{H})$ \\
\hline 19 & $39.4 \mathrm{t}$ & $1.37 * ; 2.04(\mathrm{dt} ; 9.5,3.5)$ & $39.7 \mathrm{t}$ & $1.33^{*} ; 1.96(\mathrm{dd} ; 3.5,8.5)$ \\
\hline 20 & $28.7 * \mathrm{~s}$ & ----- & $28.6 \mathrm{~s}$ & ----- \\
\hline 21 & $33.1 \mathrm{t}$ & $1.25(\mathrm{dt} ; 9.5,3.2) ; 1.32 *$ & $32.9 \mathrm{t}$ & $1.44 * ; 1.59 *$ \\
\hline 22 & $33.6 \mathrm{t}$ & $1.60 * ; 1.64 *$ & $33.8 \mathrm{t}$ & $1.55 * ; 1.60 *$ \\
\hline 23 & $19.4 \mathrm{q}$ & $1.02 \mathrm{~s}$ & $26.3 \mathrm{~s}$ & $0.93 \mathrm{~s}$ \\
\hline 24 & $28.7 \mathrm{q}$ & $0.95 \mathrm{~s}$ & $24.4 d$ & $1.04 \mathrm{~s}$ \\
\hline 25 & $17.5 \mathrm{q}$ & $1.13 \mathrm{~s}$ & $18.5 \mathrm{q}$ & $1.02 \mathrm{~s}$ \\
\hline 26 & $25.8 \mathrm{q}$ & $1.11 \mathrm{~s}$ & $20.6 \mathrm{q}$ & $0.86 \mathrm{~s}$ \\
\hline 27 & $29.6 \mathrm{q}$ & $0.92 \mathrm{~s}$ & $29.5 \mathrm{q}$ & $0.83 \mathrm{~s}$ \\
\hline 28 & $21.1 \mathrm{q}$ & $0.90 \mathrm{~s}$ & $23.9 \mathrm{q}$ & $1.00 \mathrm{~s}$ \\
\hline 29 & $33.5 \mathrm{q}$ & $0.95 \mathrm{~s}$ & $33.1 \mathrm{q}$ & $0.87 \mathrm{~s}$ \\
\hline 30 & $29.6 \mathrm{q}$ & $0.83 \mathrm{~s}$ & $29.7 \mathrm{q}$ & $0.71 \mathrm{~s}$ \\
\hline
\end{tabular}

Figure 3. Ball and Stick minimized energy model for 5.

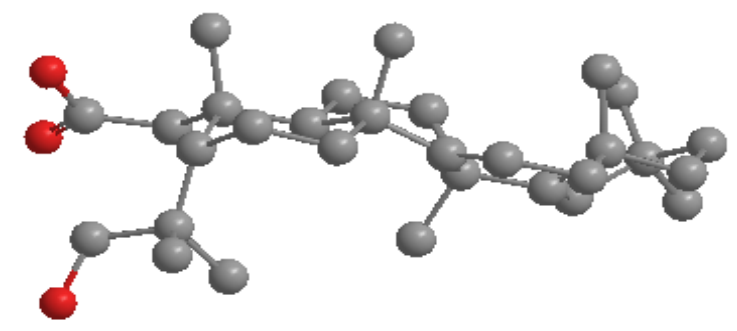

The five compounds 1-5 were examined for their dose-response effect on the viability of HeLa, HT-29, MCF-7 and KMST-6 cells using the WST-1 assay (Figure 4). All the compounds isolated from $P$. pycnantha leaves inhibited the growth of cancer cell on specific cell lines except $\mathbf{4}$ from fraction $\mathrm{P} 4$ which did not show cytotoxicity on HeLa and HT-29 cells at the dosages used in this study. The cytotoxicity activity ranged from low to moderate to high. The results from the WST-1 assay were used to determine the $\mathrm{IC}_{50}$ values for all the compounds on the four cell lines. Generally, the highest cytotoxicity was demonstrated by ursolic acid (1) with an $\mathrm{IC}_{50}$ value of $10 \mu \mathrm{M}$ on HeLa and HT-29 cells and $20 \mu \mathrm{M}$ on MCF-7 cells (Table 2). Compound 2 was moderately cytotoxic with $\mathrm{IC}_{50}$ values of 50, 100 and $60 \mu \mathrm{M}$ on HeLa, MCF-7, and HT-29 respectively (Table 2). Compounds 3 and 4 were weakly cytotoxic on all cancer cell lines and non- cytotoxic to the non-cancerous cell line KMST-6. The $\mathrm{IC}_{50}$ value of 3 ranged from $180 \mu \mathrm{M}$ to $300 \mu \mathrm{M}$ on the cancer cells. The new compound 4 displayed cytotoxicity to the adenocarcinoma cell line, MCF-7 with an $\mathrm{IC}_{50}$ value of $20 \mu \mathrm{M}$ while it was non cytotoxic on other cell lines, including the non-cancerous cell line KMST-6. The selectivity index (SI) for 4 was $>30$ for MCF-7 cells, demonstrating that the activity of this compound is highly selective for MCF-7 cells. Compound 5 was also highly cytotoxic to MCF-7 cells and the non-cancerous KMST-6 cells with $\mathrm{IC}_{50}$ value of $10 \mu \mathrm{M}$. Compound 5 was only moderately cytotoxic on HeLa and HT-29 cells with $\mathrm{IC}_{50}$ values of $180 \mu \mathrm{M}$ and $170 \mu \mathrm{M}$, respectively. Generally, the $\mathrm{IC}_{50}$ 
values for ursolic acid (1) on all cell lines tested in this study was lower compared to $\mathbf{2}$ and $\mathbf{3}$. This is an indication that ursolic acid was more cytotoxic than its 27-ester derivatives. A similar trend was observed by Shao et al. [32] where it was suggested that the introduction of bulky groups containing benzene to the $3-\mathrm{OH}$ position could increase the steric hindrance and decrease binding to the target.

Figure 4. Effect of compounds 1-5 on cell viability of (A) HeLa cells (B) HT-29 (C) MCF-7 (D) KMST-6 in a concentration dependent manner as measured by WST-1 assay.

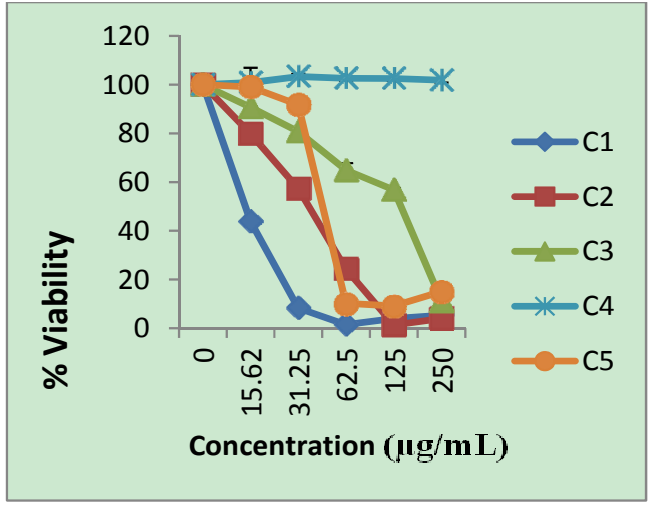

(A)

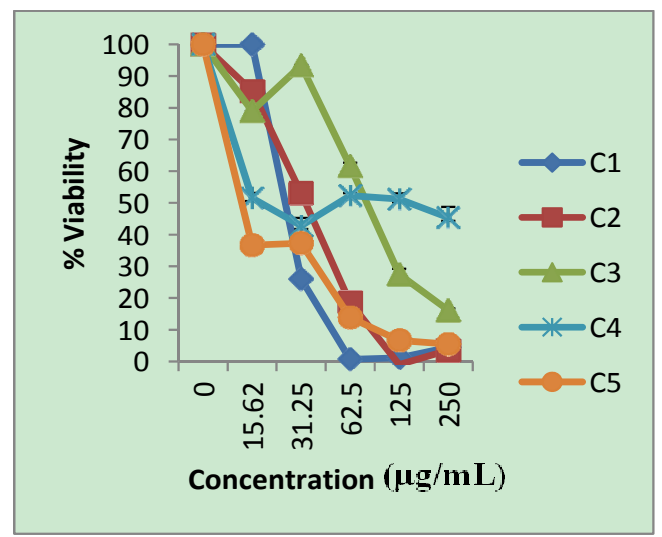

(C)

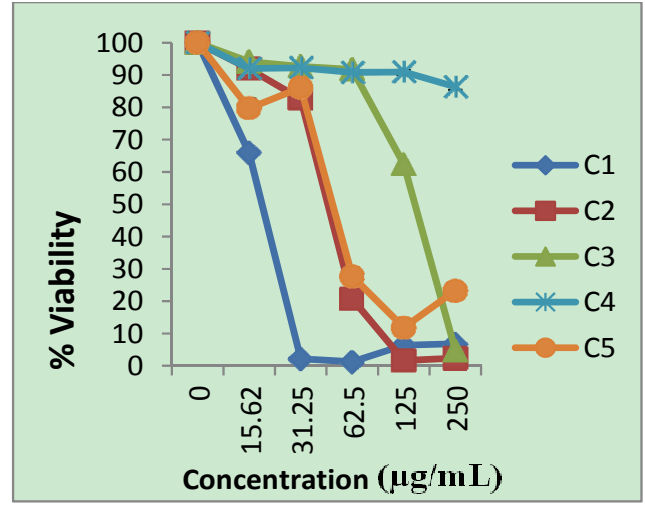

(B)

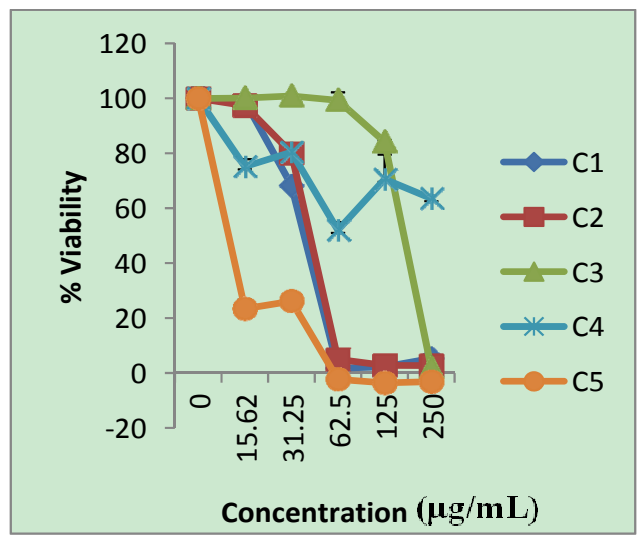

(D)

Table 2. $\mathrm{IC}_{50}(\mu \mathrm{M})$ values for compounds $\mathbf{1}-\mathbf{5}$ as determined by WST-1 assay.

\begin{tabular}{|c|c|c|c|c|c|c|c|}
\hline \multirow{3}{*}{ Compound } & \multicolumn{7}{|c|}{ Cell lines } \\
\hline & \multicolumn{2}{|c|}{ HeLa } & \multicolumn{2}{|c|}{ HT-29 } & \multicolumn{2}{|c|}{ MCF-7 } & \multirow{2}{*}{$\frac{\text { KMST-6 }}{\text { IC }_{50}}$} \\
\hline & $\mathrm{IC}_{50}$ & SI & $\mathrm{IC}_{50}$ & SI & IC $_{50}$ & SI & \\
\hline 1 & 10 & 10.0 & 10 & 10.0 & 20 & 5.0 & 100 \\
\hline 2 & 50 & 2 & 100 & 1 & 60 & 1.7 & 100 \\
\hline 3 & 200 & 1.5 & 230 & 1.3 & 180 & 1.7 & 300 \\
\hline 4 & $>600$ & ----- & $>600$ & ----- & 20 & $>30$ & $>600$ \\
\hline 5 & 180 & 0.06 & 170 & 0.06 & 10 & 1 & 10 \\
\hline
\end{tabular}

Selectivity Index $(\mathrm{SI})=\mathrm{IC}_{50}(\mathrm{KMST}-6) / \mathrm{IC}_{50}(\mathrm{HeLa})$ or any of the cancer cell lines used.

Cancer being the second largest disease makes a sizeable contribution to the total number of deaths. The World Cancer Report documented that cancer rates are set to increase globally at an alarming 
rate [33]. Plants usage has been the basis of prevention and treatment of diseases for centuries and it is thus not surprising that development of anticancer drugs today started from their preliminary cytotoxicity screening. Ursolic acid (1) is an ursane type triterpene found mainly in the leaves and displays several important biological activities viz: anti-inflammatory, antioxidant and anti-cancer properties [34]. Compound 3 has been reported to have potent activity against acetyl CoA cholestryl acyl tranferase (ACAT) [35]. The anti-proliferative activity of ursolic acid (1) has been reported in a wide variety of cancer cell lines [36]. Ursolic acid hydroxycinnamate esters isolated from cranberry fruit has been evaluated for anti-tumour activity in a 60 tumour cell line panel through the National Cancer Institute's Developmental Therapeutics program. The research showed that the esters inhibited the growth of lung, colon, breast, renal and leukemia cancer cell lines with $\mathrm{GI}_{50}$ ranging from 1.2-11 $\mu \mathrm{M}$ based on sulforhodamine $\mathrm{B}(\mathrm{SRB})$ assay [37]. The cis- and trans- isomers of 3-O-p-hydroxycinnamoyl ursolic acid has been reported to inhibit tumour growth in vitro with the cis-3-O-p-hydroxycinnamoyl ursolic acid showing slightly greater activity in most cell lines with $\mathrm{GI}_{50}$ values $\sim 20 \mu \mathrm{M}$ in MCF-7 breast, ME 180 cervical, and PC3 prostate tumour cell lines [38]. The anti-proliferative activity hydroxycoumaroyl esters of ursolic acids were reported on A-549, HCT-15, MCF-7, HT-1197 with $\mathrm{IC}_{50}$ ranging from 0.5 to $6.5 \mu \mathrm{g} / \mathrm{mL}$, from Uncaria rhynchophylla [39]. Many plants from Apocynaceae family have been reported for anticancer activity [40], including this report, which indicated the importance of their constituents as an interesting source for the discovery of new anticancer agents.

\section{Experimental}

\subsection{General}

NMR Spectra were measured on 200 Gemini-Varian (Varian Associates Inc., Palo Alto, CA, USA) and $400 \mathrm{MHz}$ Bruker (Bruker BioSpin Corporation, Billerica, MA, USA) NMR spectrometers and the chemical shifts were expressed in ppm relative to $\mathrm{CDCl}_{3}$ signal $\left(7.24 \mathrm{ppm}\right.$ for ${ }^{1} \mathrm{H}$, and $77.00 \mathrm{ppm}$ for $\left.{ }^{13} \mathrm{C}\right)$. TOF-ESI-MS spectra were measured using a HP-5 ms $(30 \mathrm{~m} \times 0.25 \mathrm{~mm}$ ID, $0.25 \mu \mathrm{m}$ film thickness) column on a Waters GCT system (Waters Corporation, Milford, MI, USA) equipped with a CTC CombiPAL Autosampler (Agilent Technologies, Santa Clara, CA, USA). IR spectra were recorded on a Perkin Elmer Spectrum 400 spectrometer (PerkinElmer, MA, USA). An Agilent 1100 HPLC system (Agilent Technologies, Santa Clara, CA, USA) consisting of a quaternary solvent delivery system, an on-line degasser, an auto-sampler, a column temperature controller and ultraviolet detector coupled with an analytical workstation and Discovery ${ }^{\circledR} \mathrm{C} 18$ column, $5 \mu \mathrm{m}, 250 \mathrm{~mm} \times 10 \mathrm{~mm}$ i.d. (Sigma-Aldrich, St. Louis, MO, USA). TLC was performed on normal phase Merck Silica gel $60 \mathrm{~F}_{254}$ on pre-coated aluminium plates $(0.2 \mathrm{~mm}$; Merck, Dermstadt, Germany). Column chromatography was carried out using 60 Å silica gel (230-400 mesh; Merck).

\subsection{Plant Material}

Pleiocapa pycnantha (K. Schum.) Stapf was collected in Ikere Ekiti, Ekiti State, Nigeria in December, 2010. The botanical identification was done by Femi Omotayo of the Herbarium section of 
Plant Science Department of Ekiti State University, Ado-Ekiti, Nigeria, where a voucher specimen was deposited.

\subsection{Extraction and Isolation}

The ground air-dried leaves $(\sim 1.0 \mathrm{~kg})$ were soaked in $95 \%$ ethanol for three days and the extract then filtered and concentrated in vacuum at $\sim 40{ }^{\circ} \mathrm{C}$ to yield $81.0 \mathrm{~g}$ of the extract. Part $(62.0 \mathrm{~g})$ of the total extract was applied on silica gel column and eluted with a mixture of hexane-EtOAC of increasing polarity. Fractions showing similar TLC characteristics were pooled together and concentrated in vacuum, giving rise to 13 fractions coded P1-P13 that were screened for cytotoxicity using WST-1 assay. Fraction P4, P7, P8 and P9 displayed strong cytotoxicity while P12 was moderately cytotoxic and were submitted for further purification. P9 (4.0 g) was chromatographed on a silica gel column using gradient elution with EtOAc/hexane (20:80-100:0) to afford Q1-13; Q4 (310 mg) was crystallized from 10\% hexane/EtOAc to give compound 1 (100 mg). P12 (5.2 g) was chromatographed on silica gel column using EtOAc/hexane (50:50-100:0) to afford sub-fraction A-H. P12E (140 mg) was further purified on sephadex LH-20 column using DCM/MeOH(95:5) and HPLC $\left(\mathrm{MeOH} / \mathrm{H}_{2} \mathrm{O}, 80: 20\right)$ to afford compound $2(5.5 \mathrm{mg})$ and $3(7.3 \mathrm{mg})$. Fraction $\mathrm{P} 4(6.0 \mathrm{~g})$ was chromatographed on silica gel using EtOAc/hexane (2:98-100:0) to give T1-T10, sub-fraction T6 was recrystallized from hexane to produce compound $4(0.97 \mathrm{~g})$. Compound 5 was synthesized by refluxing $33.0 \mathrm{mg}$ of $4 \mathrm{in}$ methanolic/KOH (5.0\%) for $3 \mathrm{~h}$ to afford $\mathrm{R} 1$ mixture which was purified on silica gel column using hexane/EtOAC (70:30) to yield $20 \mathrm{mg}(60 \%)$.

\subsection{Spectra Data}

Pycanocarpine (4). Needle-like crystals, $\mathrm{mp} 246-249{ }^{\circ} \mathrm{C}$; IR (KBr) $\mathrm{V}_{\max } 3054,2914,2856,1738$, 1474, $1077 \mathrm{~cm}^{-1}$. TOF-ESI-MS $\mathrm{m} / z 441.3735[\mathrm{M}+\mathrm{H}]^{+}$(calcd 440.3654 for $\left.\mathrm{C}_{30} \mathrm{H}_{48} \mathrm{O}_{2}\right),{ }^{1} \mathrm{H}$ and ${ }^{13} \mathrm{C}-\mathrm{NMR}$ data see Table 1.

2,3-Seco-3-hydroxy-taraxer-14-en-3-oic acid (5); Off-white amorphous powder, mp 237-241 ${ }^{\circ} \mathrm{C}$; IR $(\mathrm{KBr}) V_{\max } 3055,2921,2857,1740,1473,1067 \mathrm{~cm}^{-1}$; TOF-ESI-MS $\mathrm{m} / z \quad 459.3889[\mathrm{M}+\mathrm{H}]^{+}$ (calcd 458.3760 for $\mathrm{C}_{30} \mathrm{H}_{50} \mathrm{O}_{3}$ ); ${ }^{1} \mathrm{H}$ and ${ }^{13} \mathrm{C}-\mathrm{NMR}$ data see Table 1 .

\subsection{X-ray Structure Determination of $\mathbf{4}$}

Single-crystal X-ray diffraction data [41] were collected on a Bruker KAPPA APEX II DUO diffractometer (Bruker BioSpin Corporation, Billerica, MA, USA)) using graphite-monochromated Mo-K $\alpha$ radiation $(\chi=0.71073 \AA)$. Data collection was carried out at $173(2) \mathrm{K}$. Temperature was controlled by an Oxford Cryostream cooling system (Oxford cryosystems Ltd, Oxford, UK). Cell refinement and data reduction were performed using the program SAINT [42]. The data were scaled and absorption correction performed using SADABS [43].

The structure was solved by direct methods using SHELXS-97 and refined by full-matrix least-squares methods based on $\mathrm{F}^{2}$ using SHELXL-97 [43] and using the graphics interface program $\mathrm{X}$-Seed $[44,45]$. The programs X-Seed and POV-Ray [46] were both used to prepare molecular graphic images. All non-hydrogen atoms were refined anisotropically. All hydrogen atoms were placed 
in idealised positions and refined in riding models with $\mathrm{U}_{\text {iso }}$ assigned the values to be 1.2 or 1.5 times those of their parent atoms and the constraint distances of $\mathrm{C}-\mathrm{H}$ ranging from $0.95 \AA$ to $1.00 \AA$. The structure was refined to $\mathrm{R}$ factor of 0.0483 . The Flack $\times$ parameter is equal to -0.0123 with 1.3609 .

\subsection{Culture of Cell Lines}

HeLa, HT-29, MCF-7 and KMST-6 cells were prepared from our laboratory stocks. Briefly, cell monolayers were maintained in Dulbecco's modified Eagle's (DMEM, Lonza Group Ltd., Base, Switzerland) medium with phenol red supplemented with $10 \%$ foetal bovine serum (FBS, Biochrom AG, Berlin, Germany) and 1\% Penicillin-streptomycin (Lonza Group Ltd.). All cells were maintained in a humidified incubated at $37{ }^{\circ} \mathrm{C}$ in an atmosphere of $5 \% \mathrm{CO}_{2}$. The cells were harvested using trypsin (Lonza Group Ltd.), and viable cell concentrations were determined using the Countess ${ }^{\circledR}$ Automated Cell Counter (Invitrogen, CA, USA). $5 \times 10^{4}$ viable cells were added to each well of a 96-well tissue culture plate and incubated overnight at $37^{\circ} \mathrm{C}$ under $5 \% \mathrm{CO}_{2}$ in a humidified incubator to allow cells to attach to wells.

\subsection{WST-1 Based Cytotoxicity Assay}

Cell viability was measured using the WST-1 assay (Roche Diagnostics GmbH, Mannheim, Germany) as previously described by Ngamwongsatit et al., 2008. Cells were plated in 96-well cell culture plates at a concentration of $5 \times 10^{4}$ cells/well in $100 \mu \mathrm{L}$ culture medium. After $24 \mathrm{~h}$ the cells were treated with increasing concentrations of ethanol extract $(0-2 \mathrm{mg} / \mathrm{mL})$, fractions $(0-2 \mathrm{mg} / \mathrm{mL})$ and purified compounds $(0-250 \mu \mathrm{g} / \mathrm{mL})$ for a further $24 \mathrm{~h}$. The extracts, fractions and compounds were prepared in DMSO and then mixed with the culture medium. The final concentrations of the DMSO were less than $0.1 \%$. Following $24 \mathrm{~h}$ treatment, $10 \mu \mathrm{L}$ of cell proliferation reagent WST-1 was added and the plates were incubated for $4 \mathrm{~h}$ at $37{ }^{\circ} \mathrm{C}$ under $5 \% \mathrm{CO}_{2}$ in a humidified incubator. The plates wereshakenfor $1 \mathrm{~min}$ on a shaker and the absorbance of the samples were measured at $450 \mathrm{~nm}$ (reference wavelength was $750 \mathrm{~nm}$ ) on a micro-plate reader. The cell viability was calculated using the following formula:

$$
\% \text { Viability }=\mathrm{OD}_{\text {treated well }}-\mathrm{OD}_{\text {blank }} / \mathrm{OD}_{\text {untreated well }}-\mathrm{OD}_{\text {blank }}
$$

$\mathrm{IC}_{50}$ values were calculated using Prism Graph pad software. Triplicate experiments were conducted and the results expressed as mean $\pm \mathrm{SEM}$.

\section{Conclusions}

The phytochemical study of the ethanolic extract from the leaves from Pleiocarpa pycnantha has led to the isolation a new traxerane-type triterpenoid, in addition to three known compounds. 2,3-Seco triterpenoids are rare in Nature and compound 4 represents the first example of this type to be isolated from the Apocynaceae family. This is the first report of the isolation of triterpenes from the plant and to the best of our knowledge, the first significant bioactivity report. Our studies suggested that pure compounds isolated from Pleiocarpa pycnantha demonstrate cytotoxic activity against cervical, breast and colon cancer. 


\section{Acknowledgments}

We are grateful to Peter (UCT) for assistance with 2D-NMR analysis and Ronnie Dreyer (UCT) for assistance with flow cytometry. We are also thankful to Femi (EKSU) for collection of the plants and Hong Su (UCT) for X-ray crystallography. We also thank Prof. Benjamín Rodríguez, CSIC, Madrid, Spain, for revision of the article.

\section{Author Contributions}

O.A.O. assisted with conception and design of experiment, acquisition of data, and drafting of the article, M.M. and A.A.H. were involved in design of experiment and interpretation of data while I.G. and E.I. assisted with experimental design, thorough editing and revision of article.

\section{Conflicts of Interest}

The authors declare no conflict of interest.

\section{References}

1. Trease, G.E.; Evans, W.C. Pharmacognosy, 14th ed.; W.B. Saunders: London, UK, 1996.

2. Samuelsson, G. Drugs of Natural Origin. A Textbook of Pharmacognosy; Swedish Pharmaceutical Press: Stockholm, Sweden, 2004.

3. Brouwer, N.; Liu, Q.; Harrington, D.; Kohen, J.; Vemulpad, S.; Jamie, J.; Randall, M.; Randall, D. An ethnopharmacological study of medicinal plants in New South Wales. Molecules 2005, 10, 1252-1262.

4. Adebayo, J.O.; Krettli, A.U. Potential antimalarials from Nigerian plants: A review. J. Ethnopharmacol. 2011, 133, 289-302.

5. Helms, S. Cancer prevention and therapeutics: Panax ginseng. Altern. Med. Rev. 2004, 9, 259-274.

6. Cos, P.; Vlietinck, A.J.; Berghe, D.V.; Maes, L. Anti-infective potential of natural products: How to develop a stronger in vitro 'proof-of-concept'. J. Ethnopharmacol. 2006, 106, 290-302.

7. World Health Organization (WHO). Traditional Medicine. Avalible online: http://www.who.int/ topics/traditional_medicine/en/(accessed on 25 March 2013).

8. Le Grand, A.; Wondergem, P. Herbal Medicine and Health Promotion. A Comparative Study of Herbal Drugs in Primary Health Care; Royal Tropical Institute: Amsterdam, The Netherlands, 1989; pp. 7-20.

9. Cordell, G.A. Changing strategies in natural products chemistry. Phytochemistry 1995, 40, 1585-1612.

10. Siegel, R.; Naishadham, D.; Jemal, A. Cancer Statistics 2012. Cancer J. Clin. 2012, 62, 10-29.

11. Hartwell, J.L. Plants Used Against Cancer; Quarterman: Lawrence, MA, USA, 1982.

12. Cragg, G.M., Kingston, D.G.I., Newman, D.J., Eds. Anticancer Agents from Natural Products; Brunner-Routledge Psychology Press, Taylor \& Francis Group: Boca Raton, FL, USA, 2005.

13. Newman, D.J.; Cragg, G.M.; Snader, K.M. Natural products as sources of new drugs over the period 1981-2002. J. Nat. Prod. 2003, 66, 1022-1037.

14. Wiart, C. Medicinal Plants of Asia and the Pacific; CRC Press/Taylor \& Francis: Boca Raton, FL, USA, 2006. 
15. Gan, L.S.; Yang, S.P.; Wu, Y.; Ding, J.; Yue, J.M. Terpenoid indole alkaloids from Winchia calophylla. J. Nat. Prod. 2006, 69, 18-22.

16. Lim, S.H.; Sim, K.M.; Abdullah, Z.; Hiraku, O.; Hayashi, M.; Komiyama, K.; Kam, T.S. Leuconoxine, kopsinitarine, kopsijasmine, and kopsinone derivatives from Kopsia. J. Nat. Prod. 2007, 70, 1380-1383.

17. Wang, G.C.; Zhong, X.Z.; Zhang, D.M. Two pairs of epimeric indole alkaloids from Catharanthus roseus. Planta Med. 2011, 77, 1739-1741.

18. Macabeo, A.P.G.; Vidar, W.S.; Chen, X.; Decker, M.; Wan, J.H.B.; Franzblau, S.G.; Galvez, E.V.; Aguinaldo, M.A.M.; Cordell, G.A. Mycobacterium tuberculosis and cholinesterase inhibitors from Voacanga globosa. Eur. J. Med. Chem. 2011, 46, 3118-3123.

19. Aremu, A.O.; Finnie, J.F.; van Staden, J. Potential of South African medicinal plants used as anthelmintics-Their efficacy, safety concerns and reappraisal of current screening methods. S. Afr. J. Bot. 2012, 82, 143-150.

20. Burkill, H.M. The Useful Plants of West Tropical Africa 2nd Edition Volume 1, Families A-D; Royal Botanic Gardens: Kew, Richmond, UK, 1985; p. 960.

21. Fatumbi, V.P. Ewé: The Use of Plants in Yoruba Society; Editora Schwarcz LTDA: Sao Paulo, PB, Brazil, 1995.

22. Gorman, A.A.; Schmid, H. Structure of dimeric indole alkaloid pycnanthinine. Monatsh. Chem. 1967, 98, 1554-1566.

23. Gorman, A.A.; Dastoor, N.J.; Manfred, H.; von Philipsborn, W.; Renner, U.; Schmid, H. Alkaloids. CXXXII. Constitution of two new type dimeric indole alkaloids, pycnanthine and pleiomutinine. Helv. Chim. Acta 1969, 52, 33-55.

24. Keawpradub, N.; Houghton, P.J.; Eno-Amooquaye, E.; Burke, P.J. Activity of extracts and alkaloids of Thai Alstonia species against human lung cancer cell lines. Planta Med. 1997, 63, 97-101.

25. Seebacher, W.; Simic, N.; Weis, R.; Saf, R.; Kunert, O. Complete assignments of ${ }^{1} \mathrm{H}$ and

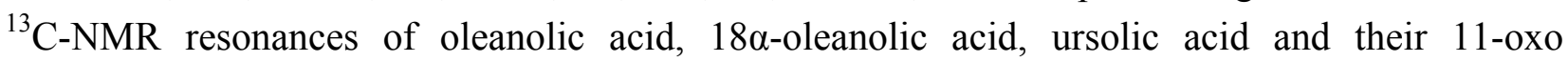
derivatives. Magn. Reson. Chem. 2003, 41, 636-638.

26. Fontanay, S.; Grare, M.; Mayer, J.; Finance, C.; Duval, R.E. Ursolic, oleanolic and betulinic acids: Antibacterial spectra and selectivity indexes. J. Ethnopharmacol. 2008, 120, 272-276.

27. Siddiqui, S.; Siddiqui, B.S.; Naeed, A.; Begum, S. Three pentacyclic triterpenoids from the leaves of Plumeria obtusa. J. Nat. Prod. 1990, 53, 1332-1336.

28. Budzikiewicz, H.; Thomas, H. p-Cumaroxy-ursolsaure, ein neuer inhaltstoff von Ilex aquifolium. L. Z. Naturforsch. 1980, 35, 230-231.

29. Danylec, B.; Iskander, M. ${ }^{1} \mathrm{H}-\mathrm{NMR}$ measurement of the trans-cis photoisomerization of cinnamic acid derivatives. J. Chem. Ed. 2002, 79, 1000-1001.

30. Mahato, S.B.; Kundu, A.P. ${ }^{13}$ C-NMR Spectra of pentacyclic triterpenoids-A complication and some salient features. Phytochemistry 1994, 37, 1517-1573.

31. Tu, H.Y.; Huang, A.M.; Wei, B.L.; Gan, K.H.; Hour, T.C.; Pu, Y.S.; Lin, C.N. Ursolic acid derivatives induce cell cycle arrest and apoptosis in NTUB1 cells associated with reactive oxygen species. Bioorg. Med. Chem. 2009, 17, 7265-7274.

32. Shao, J.W.; Dai, Y.C.; Xue, J.P.; Wang, J.C.; Lin, F.P.; Guo, Y.H. In vitro and in vivo anticancer activity evaluation of ursolic acid derivatives. Eur. J. Med. Chem. 2011, 46, 2652-2661. 
33. World Health Organization (WHO). Media Centre. Available online: http://www.who.int/ mediacentre/news/releases/2003/pr27/en/ (accessed on 1 July 2013).

34. Silva, J.A.; Silva, A.G.; Alves, A.S.; Reis, R.; Nascimento, C.C.; Diré, G.F.; Barreto, A.S. Plumeria rubra (Apocynaceae): A good source of ursolic acid. J. Med. Plants Res. 2013, 7, 892-896.

35. Nishimura, K.; Fukuda, T.; Miyase, T.; Noguchi, H.; Chen, X.M. Activity-guided isolation of triterpenoid acyl CoA cholesteryl acyl transferase (ACAT) inhibitors from Ilex kudincha. J. Nat. Prod. 1999, 62, 1061-1064.

36. Neto, C.C. Cranberry and its phytochemicals: A review of in vitro anticancer studies. J. Nutr. 2007, 137, 186S-193S.

37. Kondo, M. Phytochemical Studies of Extracts from Cranberry (Vaccinium macrocarpon) with Anti-Cancer, Anti-Fungal and Cardioprotective Properties. M.S. Thesis, University of Massachusetts, Massachusetts, MA, USA, 2006.

38. Hamzah, A.S.; Lajis, N.H. Chemical constituents of Hedyotis herbacea. ARBEC 1998, article II. Available online: http://www.arbec.com.my/pdf/may-2.pdf (accessed on 11 March 2014).

39. Lee, J.S.; Kim, J.; Kim, B.Y.; Lee, H.S.; Ahn, J.S.; Chang, Y.S. Inhibition of Phospholipase C $\gamma 1$ and Cancer Cell Proliferation by Triterpene Esters from Uncaria rhynchophylla. J. Nat. Prod. 2000, 63, 753-756.

40. Okouneva, T.; Hill, B.T.; Wilson, L.; Jordan, M.A. The effects of vinflunine, vinorelbine, and vinblastine on centromere dynamics. Mol. Cancer Ther. 2003, 2, 427-436.

41. Crystallographic data (excluding structure factors) for the structures reported in this paper have been deposited with the Cambridge Crystallographic Data Centre as supplementary crystallographic data (CCDC 972299) for 4 and can be obtained free of charge via www.ccdc.cam.ac.uk/conts/retrieving.html (or from the Cambridge Crystallographic Data Centre, 12 Union Road, Cambridge CB21EZ, UK; fax: (+44) 1223-336-033; or deposit@ccdc.cam.ac.uk).

42. Bruker. SAINT Version 7.60a; Bruker AXS Inc.: Madison, WI, USA, 2006.

43. Sheldrick, G.M. SHELXS-97, SHELXL-97 and SADABS Version 2.05; University of Göttingen: Göttingen, Germany, 1997.

44. Barbour, L.J. X-Seed-A Software Tool for Supramolecular Crystallography. J. Supramol. Chem. 2001, 1, 189-191.

45. Atwood, J.L.; Barbour, L.J. Molecular Graphics: From Science to Art. Cryst. Growth Des. 2003, 3, 3-8.

46. POV-Ray for Windows (Version 3.6). Persistence of Vision Raytracer Pty. Ltd.: Victoria, Australia. Available online: http://www.povray.org (accessed on 12 March 2004).

Sample Availability: Samples of the compounds 1-5 are available from the authors.

(C) 2014 by the authors; licensee MDPI, Basel, Switzerland. This article is an open access article distributed under the terms and conditions of the Creative Commons Attribution license (http://creativecommons.org/licenses/by/3.0/). 